Financial Markets, Institutions and Risks, Volume 3, Issue 4, 2019

ISSN (online) - 2521-1242 ISSN (print) - 2521-1250

\title{
Evaluating the changes in the European Banking Regulation - MiFID and its possible effects on the Global Economy: A Theoretical Study
}

\author{
Shahriar Tanjimul Islam, ORCID: https://orcid.org/0000-0003-1405-4395 \\ Lecturer, College of Business Administration, IUBAT- International University of Business Agriculture and \\ Technology, Dhaka, Bangladesh
}

Md Yusuf Hossein Khan, ORCID: https://orcid.org/0000-0002-5981-8849

Ph.D. Researcher in Tourism, University of Algarve, Faro, Portugal, Assistant Professor, College of Tourism and Hospitality Management, IUBAT - International University of Business Agriculture and Technology Dhaka, Bangladesh

\begin{abstract}
Banking regulation plays an important role in the process of ensuring financial stability, the national economy, equitable distribution of wealth and the most efficient use of financial resources. As a key regulatory tool, Banking Regulation monitors and monitors financial transactions to improve their profitability and efficiency. The author points out that the main areas of banking regulation and supervision are to control the processes of formation, operation and liquidation of commercial banks. The article focuses on the fact that the 2008 financial crisis has become a motivating driver for reforms in the banking system of Europe and America. The main purpose of the article is to assess the impact of changes in the European Banking System, in particular in the context of the study of the features of the Financial Markets Directive, on the functioning of the global economy. This paper provides a critical review of the literature from the point of view of analyzing the specificity of MiFID II in the context of its impact on the economic aspects of the country's development. The implementation of the Directive requires significant financial investment, but these costs will pay off given the fact that MiFID II is well-designed and aimed at providing more secure protection and greater customer base stability. However, the author points out the underdevelopment and inconsistency of the regulatory framework, which is of greater concern than the cost of implementing MiFID II. Thus, the idea of the likelihood of financial and economic problems in the process of influence of banking regulation on the development of the global economy is substantiated. Notwithstanding these shortcomings, the regulatory framework for the formulation and implementation of the Directive is a significant contribution to the regulation of the financial sector. The results of the study represent scientific and practical value for academics, politicians, banking financial management of economic entities, stakeholders to better prepare and evaluate future changes as a result of reforming banking regulation.
\end{abstract}

Key words: Directives, Economic growth, Financial crisis, MiFID, Regulation.

JEL Classification: E58, G21, P33.

Cite as: Islam, S.T., Khan, M.Y.H. (2019). Evaluating the changes in the European Banking Regulation MiFID and its possible effects on the Global Economy: A Theoretical Study. Financial Markets, Institutions and Risks, 3(4), 24-31. http://doi.org/10.21272/fmir.3(4). 24-31.2019.

(C) The Authors, 2019. This article is published with open access at Sumy State University.

\section{Introduction}

The effects of post 2008 financial crisis were one of the most severe things, which still exist in the living memory. Its effects are still being felt today. Since after the collapse of the financial market in 2007, the EU financial regulatory structure has started reforming at a great pace and has made a great deal of changes within. The changes that have taken places were not only for the sake of improving the economic governance of EU Member States but also to strengthen the supervisory and regulatory structure of financial regulation and institutions themselves. Such changes are taking place in the hope of not repeating the mistakes which took place during that time. This paper intends to focus on the European Financial regulation; however, more importantly it will discuss MiFID (Markets in Financial Directive) and MiFID II and it costs to the economy. The paper will observe the regulatory changes and what this new MiFID II will put as an impact on EU and to the global economy, will be the main highlight of the discussion.

To talk a little about MiFID II, this is being fully implemented by Financial Conduct Authority (FCA) and 
Financial Markets, Institutions and Risks, Volume 3, Issue 4, 2019

ISSN (online) - 2521-1242 ISSN (print) - 2521-1250

European Financial Regulatory body by 2017. Still lot of revising and discussion is taking place and few large companies are showing some concerns of these upcoming new changes. Through examining this paper, one of its major findings will be whether a risk over regulation took place or not and have slowed the growth of the economy (i.e. financial stability vs. growth). With all of these findings, this paper aims to argue that whether these new upcoming changes, particularly MiFID was a much-needed change or whether it is just an overreaction from the regulatory system after the crisis.

\section{Aim of the Research}

The aim of this paper is to create more awareness of this new system (i.e. MiFID II) to the banking officials, authority and academicians, stakeholders, government officials who are into the fields of Finance. With a collection of different literatures this will try to break down the need for changes in the banking industry.

\section{Research Methodology}

To understand the research objectives, it is very crucial to understand the research methodology. In accordance to Creswell (2003), philosophical ideas remain mostly hidden in the research, but they still influence the practice of the research and hence have to be identified. Collis and Hussey (2003) also share their view that the research philosophy has a strong implication on the choice of methodology and the methods of collecting data. Saunders et al (2003) also informs that there are three philosophies that dominate the literaturepositivism, interpretivism and realism. These views are all different if not equally exclusive views of how knowledge is developed and judged as being acceptable.

In this paper an element of two research philosophy will be eminent- Interpretivism and realism. While doing this work, there has been a fair amount of flexibility, imagination, deduction and had a comprehensive approach to meet the objectives. The data are vastly descriptive and hardly quantitative. As in this research various journals and papers for critical evaluation in the literature review as to obtain the research objective, hence it is more tilted towards inductive research approach. On the other hand, it is not quantifiable, or its research process is not repeatable; therefore, it cannot have deductive research approach.

It can be understood from the fact that this research will be strongly based on the critical reviews of literature. Haran (2008) explains critical reviews of literature helps to identify gaps in the existing knowledge base. From the suggestion of Jankowicz (2005) knowledge does not exist in a void, and research only has value when it has relation to other studies. The significance of a research depends to the extent the results as the same as, or different from other findings. A 'Gnostic' approach is taken rather than from 'Orthodox'-. In 'Orthodox' approach, the truth stays as the objective, simple, transparent and must be agreed by the body of knowledge. It pinpoints issues in a very straightforward way with a transparent language. Whereas in 'Gnostic' approaches the truth is seen more as subjective, hidden and is only gained through personal struggle. The language often stays ambiguous too.

\section{Literature Review}

\section{List of Some Financial Directives of EU}

Directives play a very important role in the European Community. Putnis, Kingsley and Sholem (2014) further explains that their importance as directives are binding on their member states as to the results to be achieved but also giving some member states some discretion over how they incorporate Directives into their domestic law. To ensure the effectiveness of the Single Rulebook, in terms of ensuring 'financial stability', 'transparency' and 'consumer protection' and run the financial regulation effectively, the roles of the financial directives become very important. With these core functions of the Single Rulebook, the supporting directives are briefly explained below.

\section{Financial Stability}

According to Balfe et al (2017), the Capital Requirement Directive IV (CRD IV), the Capital Requirements Regulation (CRR) and the Bank Recover and Resolution Directive (BRRD) are at the core of the new EU regime to stabilize the financial sector.

\section{Transparency}

Several legislative measures MiFID II, MiFIR and EMIR are designed to improve transparency and flexibility in derivatives and securities markets. Particularly "MiFID II and MiFIR extend the transparency requirements already applicable to the equity market to non-equity markets" (Balfe et al, 2015, p- 48). 


\section{Consumer Protection}

After the EU's crisis-era reforms directed to strengthening consumer protection are contained for the mainly in the MiFID II, the Deposit Guarantee Schemes Directive (DGSD), and the Insurance Distribution Directive (IDD).

\section{MiFID}

MiFID's aim, implementation and will also focus on the arrival of the new MiFID and evaluate it. The national law enforced it and placed the MiFID into action for the first time by November 1, 2007, and the level two Regulation took effect on the same date. In order to enhance greater consumer protection and market transparency, MiFID was introduced. Some core functions are:

Providing authority- It requires firms which engage in specified services and activities (investment firms) to be authorized by the competent authorities of the state where they are located. Counsel the business entity about the requirements (broadly, prudential rules) and operational requirements, which is applicable to investment firms.

Passport- Another very important function of MiFID is to provide firms with passports into another state. The governing rules will be those of its home state, except if it operates as a branch state, in which the conduct of business will be those of the host state.

\section{Assessment}

These issues which are stated above were highlighted by Vives during 2001, unfortunately during the financial crisis from 2008 to 2011; it seemed to be ineffective during the crisis period. These do show that the EC lacked some proactive measures or were not efficient enough to clear those. For this regulatory failure, EC had needed to totally clear issues related crisis management, and issues involving with credit rating agencies, rise of political disputes and other factors. Since all the factors are equally important to consider the failure of the Financial Regulatory body of EU, and not just MiFID. However, after the crisis, the whole financial regulatory system of EU has taken drastic measures to change, in order to perform much better during the crisis. For instance, introducing Basel III and implementing MiFID II by 2017.

\section{MiFID II}

In October 2011, the European Commission tabled proposals to revise the MiFID with the aim of making financial markets more resilient, efficient, transparent, and strengthen the protection of investors (ec.europa.eu, 2015). It is confirmed by Prorokowski (2017) that the changes which were drafted in October 2011, has gone over 2,000 amendments.

\section{MiFID II Implementation}

MiFID II is in full action from 2017. As to the latest findings by Bayley et al (2017), he assures that the European Commission (EC) is continuing to work towards the adaptation of the delegated acts, which is likely to take place in July or September. EC and FCA are both very alert and very well co-ordinated this time and very much aware of their responsibilities. Before the implementation of this new directive, many laws and changes are discussed and assessed thoroughly. These really shows few signs that the EU Financial regulatory does not want to repeat its mistakes and fall apart again in it's crisis period.

\section{Implementation of the new changes to the MiFID}

The wide range of reforms which are to be introduced under this directive (MiFID II), as McNulty (2013) explains that it includes new controls for high frequency trading, restrictions on volumes of dark pools orders, the creation of new trading venues or organised trading facilities, setting the obligation to position limits on trading firms in certain commodity derivatives, as well as to promote competitiveness in regional derivatives market. The following changes are-

Notification of Changes- MiFID II Article 17 (2) proposes that investment firms engaging in algorithmic trading must annually to the regulator give a description of their algorithmic trading strategies, more clear specifications of the trading parameters and limits, the key risk controls and compliance which in place and lastly how their whole system is tested.

Circuit breakers- In MiFID it is the mechanism for limiting or halting on exchanges or single stock; setting its limit on the maximum rises or falls of prices in a trading period. Its purpose is to reduce the risk of a market 
collapse which is followed by a sequence of fall in trades.

Minimum tick sizes- The minimum tick size is the allowable increase between quoted prices in a market. It has important implications for both transaction costs and in liquidity provision.

Obligations for the market makers- Obligation for market makers are requirements that a person (or controversially a computer program) acting as a market maker all the time must publish prices to buy and sell at competitive levels, regardless of market conditions. This is meant to be applied for both to tradition market makers (human) or to algorithmic market makers or both ${ }^{\mathrm{i}}$.

Minimum resting time- It specifies every limit order must have a minimum time. The reasons behind imposing a minimum is that now markets feature many orders that are cancelled quickly after submission. Beddington (2012) adds that as therefore it can increase the costs off monitoring in the markets, where others are participating. It also reduces the predictability of a trade's execution quality since the quotes shown may have been cancelled by the time the market order hits the resting orders.

Order to execution ratios- This regulation puts an upper limit on the order to execution ratios (OERs) and made into such that part of the larger class restrictions on order book activity restriction being considered by policymakers on both sides. Restrictions like this encourage traders to cancel fewer orders, and thus provide a more predictable limit. It is believed by the EU regulatory body that this will help to improve the investor confidence in the market.

\section{Benefits and Costs from these new changes}

Beddington (2012) also critically discusses about the cost and benefits related with the new changes. At the end of his work he also informs that most of his findings need practical evidences in order to be proven. Few arguments are still provided with these new changes of MiFID.

\section{Benefits}

It is suggested by Beddington (2012) that market maker obligations can improve market quality and improve the social welfare. Since it's narrower spreads will encourage both informed and uninformed traders to trade more, as a result it will increase price efficiency and will help the markets to quickly discover the assets price ${ }^{\mathrm{ii}}$.

Furthermore, when it comes to orders-to execution ratios, it plays a very important role in aligning the private and social costs and thus helping social welfare to improve more. This derives from the financial market, since receiving, handling and storing messages is costly for exchanges, brokers and regulators.

\section{Costs and Risks}

With the benefits of the new regulatory changes imposed on CBT (Computer Based Trading), there are also other costs and risks involved which should equally be remembered. For instance, imposing market maker obligations on algorithmic market making trading strategies raises a variety of risks. In many high frequency trading strategies post bids and offers across correlated contracts, therefore a high frequency market maker might be buying from one market and selling in another. Since it is not a requirement to post a continuous bidoffer spread with this strategy, it creates such problem. If, however it was binding, then it could for high frequency traders out of the business of liquidity provision. Putting an upwards of such as $50 \%$ of liquidity, coming from high frequency trader, could mean more trouble.

With the 'Minimum resting times', the liquidity providers will post limit orders available for trade within a period, in return for an expected gain in the form of the bid-ask spread. Hence adding more limit orders become more costly, since posting a limit order offers a free option to the market which is exercised at the discretion of the active trader. Hence if an active trader better or newer information, the limit order which was posted previously would be adversely selected i.e. buying when the stock is going down and selling when the stock is going up. Thus, as a result it creates an increase in the bid-offer spread or decreased depth as posting limit order becomes less attractive ${ }^{\text {iii }}$.

\section{Evaluation of MiFID II (function)}

With the implication of the new MiFID, the firms are required to set several costly requirements. The Banking Technology (2014) argues that the directive requires costly investments in the areas (i.e. algorithmic trading) which are more likely to threat the market stability. At a go, the European Commission has estimated that an initial one-off implementation costs will be in the region of 512-732 m. Prokowski (2017) further adds that a big portion of its costs are related to post-trade optimization and recognizing synergies in reporting 
Financial Markets, Institutions and Risks, Volume 3, Issue 4, 2019

ISSN (online) - 2521-1242 ISSN (print) - 2521-1250

requirements for MiFID II. In order to reduce such high implementation costs, outsourcing IT processes and approaching to data management sellers has been one of such efficient ways to accomplish it.

Lord Balfe (2017) has more critically pointed out that there is a trade of between choice and protection. MiFID II imposes restrictions on the type of investment product which can be sold execution. This as a result may increase the overall protection for many retail investors, who mainly deal with the most straightforward products. While implying this, investor choice is getting reduced. These changes in MiFID II is probably going to affect most adversely to the more sophisticated retail investors, who may lose the opportunity to engage in higher-risk/higher-return investments.

One thing is certain that from outside, the changes of MiFID II to may not look as big, like its earlier versionMiFID I; however, the changes are surely very significant. Despite high implementation costs, it is still fair to say that MiFID II lands a positive step towards greater transparency, client protection and builds resilience for European securities market. Some of these hard decisions are putting major impacts. However, McNutty (2013) assures that if the rule making continues at an EU pace, policymakers' risk significantly softens the bite of reforms in a field in which market behavior and technology move considerably faster.

\section{Evaluation of new MiFID's impact on Europe and Economy- Discussion}

MiFID first came into light by 2007. However, as it is confirmed by the FCA.Org that it was the financial crisis shook this regulation (effectively) that now it is being comprehensively revised in order to improve the functioning of financial markets and to strengthen investor protection. With MiFID II emerging, it controls significant changes in business and operating models, compelling financial firms to make huge technological and structural changes. Optimistically if this matter is given with some light, then there should not be much problem. This is because this time various amendments have taken place to counter the problems if any such takes place again soon. At a glance some big changes which have taken are the formation of EU Recovery and Resolution Directive, implementing new MiFID II and Basel III and many more. Also, the way the regulatory body is managing the credit default swap and in future putting more attention to short selling is noticeable and very appreciable. It is trying to ensure that the firms avoid the unnecessary risks and move steadily for growth.

Certainly, many positive things that are being discussed above, in theory, all should work well. However, this new system does not provide any such guarantee that it will be a trouble proof system; unless its metal being tested by another financial crisis as big as the earlier ones. The regulatory body also lacked proper crisis management system and issues related with the credit rating agencies were parts of the cause. Hence the role of other financial Directives (i.e. including MiFID) and its changes should be thoroughly evaluated and everything should be taken into the account before making any generalization to say that whether the whole regulatory system will be effective or not. Other concerns arose with the risk of failure, where there are few gaps in the regulatory structure. The argument is stretched further, as Christopher Woolard emphasizes on the bonding between MiFID II, IMD II and PRIIPs (Packaged Retail and Insurance Based Investment Products) Regulation and he further goes into explaining that how this confusion still exists due to different characteristics of European domestic markets. This is because as some product are labelled as 'insurance' and whilst others are not, even when the product is the same. ${ }^{\text {iv }}$ Furthermore Aberdeen Asset Management points out that there is a conflict as with MiFID II addresses investment product and IMD II set the framework for selling insurance products, including an investment feature and this clearly overlapping as stated. Lord Balfe (2015, pp-54) also states that "ESMA would try to ensure that MiFID II and MiFIR rules were consistently implemented at national level. Yet inconsistencies of implementation could arise because of various waivers and exemptions. Some market player would accordingly seek to exploit the different rules." (Lord Balfe 2015, pp-54). Lastly and more generally Nicolas Veron has put up a more general view in regards to inconsistency stating that "... the problem of inconsistency in implementation was due to the lack of enforcement" and critically argued that "the European Commission has enforcement powers that it has not used to the extent it should have" . Further arguments suggest that there is not proper enforcement and implementation with laws which could lead to failure. Furthermore, these new changes are creating some toll on Europe as whole too. The growth of the EU has slowed down significantly, since after the financial crisis (2007-2011). One of the overriding concerns which Lord Balfe (2017) expresses is that "the legislative framework had been focused too much on stability rather than growth." (Lord Balfe, 2015, 90).

However, Michael Barnier emphasized that financial stability as an essential precondition. ${ }^{\text {vi }}$ Similarly, Andrea Enria warned that capital was necessary to assist in bank lending; and that it was risky to focus more towards support growth than stability rules ${ }^{\text {vii }}$. The growth of the economy could grow slowly because it has hit the 
economy hard and may also affect the investor's confidence level. The severity of the financial crisis is still putting its toll on the financial market and making it suffer. In the end, it is still ok to stay slightly optimistic towards Europe's economy as it is slowly recovering from its big loss. However, this time the regulatory body must become more cautious than ever as new challenges are still waiting ahead, and because of 'globalization' as trading is becoming so easier, it draws out more complexities as well. Along with these, the success of the regulation will also depend on how disputes between the EU countries are handled. Failure to handle issues like with Greece will greatly affect the market and its currency. All these are connected to MiFID II, as MiFID II itself can bring the success for the regulation; all other parts must be equally effective and should have similar goals, while not conflicting with one another. Similarly, MiFID II must ensure its part that it is working effectively and provide a better customer protection, etc.

\section{Conclusion}

This critical review of literature looks deeply into the financial regulatory frame of European Union. This literature review has helped to understand the meaningful motives, actions and intentions of those participating in the research (i.e. the EU Commission (EC), the financial regulatory body, the European Parliament and the Council of European Union). A lot of discussions took place in order assess the implementation cost of the new MiFID at 2017. These new regulations, in theory, look nice however before reaping the benefits, it itself has some costs and risks to bear. For instance, the slower growth of the economy, in order to make it more stable and investors at many cases are discouraged to take high-risk strategies hence sacrificing the opportunity to receive high returns. All these are the form of costs and issues are well discussed and argued to see whether MiFID II will be the right kind of choice for EC to implement. From the findings and research implementing MiFID II is a good choice; but only time will answer how effective it will be to combat the problems.

Sadly, what also has been found while studying this paper is the weakness of the regulatory framework and has become an even bigger issue of concern that the implementation cost of MiFID. Yet this should not reduce the significant achievement which the reformed framework represents, especially within such short amount of time. At the very end, this article intends to help many policy makers and bank officials in different ways. Firstly, this paper tries address the implication cost of this new MiFID system, in banking industry. Secondly, this paper looks deep into the regulatory framework of a bank and focuses on the positive aspects the change. There are no doubt changes were necessary, as any banking regulatory framework will want the organizations to work smoothly. This literature review can only assess and visualize the potential risks and benefits of implementing this new method, as this study is purely qualitative. This MiFID is still too new for empirical studies amongst European banks, however with quantitative analysis is needed to confirm how well other European banks are performing by using this new system.

\section{Reference}

1. Adair, A., Berry, j., McGreal, S., Deddis, B. \&Hirst, S. (1999). Evaluation of Investor Behaviour in Urban Regeneration, Urban Studies, 36(12), 2031- 2045.

2. Alderman, L., Kanter, J., Yardley, J and et al. (2017). Greece Debt Crisis Explained. Available from: http://www.nytimes.com/interactive/2015/business/international/greece-debt-crisis-euro. html?_r=0 Revised: $20^{\text {th }}$ August 2015.

3. Balfe, L., et al (2017). The Post Crisis EU Financial Regulatory Framework: Do the pieces fit in? Available from: http://www.publications.parliament.uk/pa/ld201415/ldselect/ldeucom/103/103.pdf. Chapter 1. $5^{\text {th }}$ Report, London.

4. Bayley, N. et al.(2017) Minutes of the meeting of the MIFID II Implementation Round Table.|ISd1filepw21 luserslshanks\Roundtable minutes.docx3. Round Table Minutes, London. [Accessed 27th August].

5. Bank of England. (2014) Capital Requirement directive IV. [Online] Available from: http://www.bankofengland.co.uk/pra/Pages/crdiv/default.aspx [Accessed 5th August]..

6. BBC News. (2011) Lisbon Treaty. [Online] Available from: http://news.bbc.co.uk/2/hi/europe/6901353.stm [Accessed 15th July].

7. Beddington, S.J. (2012) Economic Assessment on MiFID II policy measures related to Computer trading in Financial Markets. (Working Paper) Government office for Science.Crown Copyright (2012), 1 Victoria Street, London. 
Financial Markets, Institutions and Risks, Volume 3, Issue 4, 2019

ISSN (online) - 2521-1242 ISSN (print) - 2521-1250

8. $\quad$ Bryman, A. \& Bell, E. (2003) Business research methods. Oxford University Press: Oxford.

9. Central Banks Guide (2019) Central Banks. [Online] Avalable from: http://www.centralbanksguide.com/banking+industry+regulation/

10. Collis, J. \& Hussey, R. (2003) Business research: a practical guide for the undergraduate and postgraduate students. $2^{\text {nd }}$ Edition. Palgrave Macmillan, Basingstoke.

11. Creswell, J. W. (2003). Research design, qualitative, quantitative, and mixed approaches. $2^{\text {nd }}$ Edition. Sage Publication, London.

12. Easley et al. (2012) Insights to the High-Frequency Paradigm.Journal of Portfolio Management, 39(1).

13. EBA Europa. (2014). European Banking Authority. [Online] Available from: http://www.eba.europa.eu/about-us [Accessed 5th August].

14. Ernst Young. (2013) The world of Financial Investment Just got more complex. Capital Markets Reform: MiFID II, Global Regulatory Reform, Ernst \& Young.

15. Europa. (2014) E-Commerce Directive. [Online] Available from: http://ec.europa.eu/internal_market/ e-commerce/directive/index_en.htm [Accessed 7th August].

16. Europa. (2017). Progress of Financial Reforms. [Online] Available from: http://ec.europa.eu/finance/ general-policy/policy/map reform en.htm\#row5Last update: 20.04.2015 [Accessed 25th July].

17. FCA Organisation. (2017) MiFID Review. [Online] Available from: https://www.fca.org.uk/firms/markets/international-markets/mifid-ii/mifid-review [Accessed 29th June]. FCA Organisation.(2017) MiFID. [Online] Available from: http://www.fca.org.uk/firms/being-regulated/ meeting-your-obligations/firm-guides/guide-financial-advisers/mifid [Accessed 29th June].

18. Fisher, C., Buglear, J., Lowry, D. \&Mutch, A. Tansley, C. (2010) Researching and Writing a Dissertation: An essential guide for business students. $3^{\text {rd }}$ Edition. Prentice Hall: London

19. Gill, J. \& Johnson, P. (1997) Research methods for managers $4^{\text {th }}$ Edition. Paul Chapman Publishing, London.

20. Government UK. (2017) Extract from the Chancellor Speech on Europe. [Online] Available from: https://www.gov.uk/government/speeches/extracts-from-the-chancellors-speech-on-europe [Accessed 25th July].

21. Haran, M.E. (2008) The contribution of property Investment vehicles in financing urban registration in the UK.

22. Investopedia (2017) MiFID. [Online] Available from: https://www.investopedia.com/ terms $/ \mathrm{m} / \mathrm{mifid}$.asp [Accessed 5th August].

23. Remenyi, D., Williams, B., Money, A. \& Swartz, E. (1998) Doing research in business and management: An introduction to process and method. Sage Publications, London.

24. Oriol, N., Rufini, A. \& Torre, D. (2015 Heterogenous investors and Trading Platforms Competition.[Online] Available from: http://dx.doi.org/10.1108/JRF-11-2014-0169. The Journal ofRisk Finance, 16(3), 303- 320. [Accessed 19th August].

25. Out Law. (2017) FCA Loses fight on MiFID II. [Online] Available from: http://www.outlaw.com/en/articles/2015/july/fca-loses-fight-on-mifid-ii-call-recording/[Accessed 29th June].

26. Petitjean, M. (2013) Bank Failures and Regulation: A Critical Review. [Online] Available from: http://dx.doi.org/10.1108/13581981311297803Journal of Financial Regulation and Compliance. 21 (1), $16-38$. [Accessed 19th August].

27. Putnis, J., Kingsley, B., and Sholem, M. (2014). Introduction to the legislative processes for European Union Directives and regulations on financial services matters. Slaughter \& May. London.

28. Saunders, M., Lewis, P \&Thornhill, A. (2003). Research Methods for business students. $3^{\text {rd }}$ Edition. Prentice Hall: New York.

29. Stichele, M.V. (2008). Financial Regulation in the European Union. [Online] Available from: 
http://www.eurodad.org/uploadedfiles/whats new/reports/eumapping financial regulation final.pdf.

Chapter 1 and Conclusion. Ford Foundation.For more information- http://www.eurodad.org/ debt/?id=2190. [Accessed 7th August].

30. Stones, R. (2006) MiFID for Dummies.Internation Financial Law Review, 25(8), 22-23. London

31. UK Practical Law. (2017) Deposit Guarantee Scheme Directive. [Online]. Available from: http://uk.practicallaw.com/2-521-2166 [Accessed 7th August].

32. Vives, X. (2001). Restructuring the Financial Regulation in the European Monetary Union. Journal of Financial Services Research, 19(1), 57-82, Kluwer Academic Publishers, Netherlands. 